\title{
ORIGINAL
}

\section{Morphologic effects of maternal alcohol intake on skull, mandible and tooth of the offspring in mice}

\author{
Juan Carlos Hernandez \\ Department of Oral Pathology, Tohoku University School of Dentistry \\ 4-1 Seiryo-machi, Aoba-ku, Sendai 980, Japan \\ (Director: Prof. Kiyoshi Ooya) \\ [Accepted for publication: March 8, 1990]
}

Key words : Alcoholism / fetus / mandible / odontogenesis / mice

\begin{abstract}
Morphologic effects of maternal alcohol intake on skull, mandible and tooth of the offspring in $\mathrm{BALB} / \mathrm{cJ}$ mice were studied. Adult female mice were given orally $20 \%$ alcohol in drinking water and a diet before and during pregnancy. Maternal blood alcohol levels showed $284.0 \pm 1.4 \mathrm{mg} /$ $100 \mathrm{~m} l$ on gestation day 12.5. Skull and mandible were dissected, weighed and processed for statistical analysis and light microscopic examinations. The results were as follows: 1) The total maternal body weights showed no significant difference during pregnancy between the control and alcohol-treated groups, but the offspring of alcohol-treated females showed weight deficit through the period of gestation and postnatal 28.5 days. 2) The mandible weight of the offspring was less in the alcohol-treated group than the control group through a postnatal period of 28.5 days. 3) The growth of the skull and mandible in the offspring was retarded in the alcohol-treated group through a postnatal period of 28.5 days. Significant statistical differences of the growth were seen in the posterior region of the mandible. 4) Appearance of the tooth germ was delayed on gestation day 14.5. 5) Calcification of the tooth was delayed on postnatal day 1.5. 6) Retardation of the tooth eruption was seen on postnatal day 14.5. It is indicated that the offspring associated with maternal chronic alcoholism showed retardations in their skeletal and dental development, and failed to catch up to the growth of the control animals during a postnatal period of four weeks.
\end{abstract}

\section{Introduction}

Major advances in our understanding of alcohol (ethyl alcohol) on the prenatal and postnatal offspring have been made through clini$\mathrm{cal}^{1-3)}$ and experimental ${ }^{4-7)}$ studies. The findings which are related to the effects of alcohol during pregnancy and the resulting abnormalities on the offspring from alcoholic mothers have been termed Fetal Alcohol Syndrome (FAS) ${ }^{1}$. In the human, FAS has been categorized into three main components:(1) a general somatic growth retardation ${ }^{2}$, (2) a set of facial appearances noted in the affected offspring ${ }^{3)}$, and (3) microcephaly and mental retardation ${ }^{3,4}$.

Alcohol has been given to various laboratory animals by different routes (i.e., intravenous ${ }^{5 \text {, }}$, by gavage $^{61}$, vapor inhalation ${ }^{71}$, intraperitoneal $^{8)}$ and in drinking water $\left.{ }^{9}\right)$. However, the observations reported have not always been in agreement. This may be attributed to the diffferences of species and strains in their susceptibility to alcohol as well as those in the experimental conditions such as doses ${ }^{6}$, routes $^{51}$, periods ${ }^{10)}$ and durations ${ }^{11}$, of alcohol administration.

Little attention has been paid to the observation of dental structures in FAS. In this study, morphologic effects of maternal alcohol intake on the skull, mandible and tooth of the offspring in mice were investigated.

\section{Materials and Methods}

Virgin female $\mathrm{BALB} / \mathrm{cJ}$ mice were obtain- 
ed from Tohoku University Animal Center. The laboratory in which animals were retained for the entire experimental period was temperature, humidity and light/dark cycle controlled. The mice were given a commercial diet (F-2, Funabashi Farms, Chiba, Japan) and water. Diet and water were taken ad libitum until the beginning of the experiment.

One hundred and twelve mice were divided into 12 experimental groups (6 animals each) and 10 control groups (4 animals each). The mice were 8 weeks of age at the beginning of the experiment and weighed from 21 and 23 grams. Alcohol solutions in drinking water were given to the experimental groups. The water was replaced by increasing alcohol concentrations in the order $1 \%, 5 \%, 10$ $\%$ and $15 \%$ from day 0 to day 12 of the experiment. From day 13 to delivery, the experimental groups were kept on drinking $20 \%$ alcohol and fed on the commercial diet before and during pregnancy. The control groups were also fed on the diet and took water without alcohol ad libitum before and during pregnancy. In all groups, the liquid was given in plastic bottles $(150 \mathrm{ml})$ with a tip to diminish leakage and evaporation. Alcohol intake was measured daily. At 14 and 16 weeks of age, male mice were housed singly and mated daily with female mice between $22: 30$ and $0: 00$. The presence of a vaginal plug was designated as gestation day 0.5.

From gestation day 7.5 , pregnant females were weighed every other day. On gestation day 12.5, a blood sample was taken from the retro-orbital sinus and collected in heparinized capillary tubes. Blood alcohol levels were determined by gas-liquid chromatography according to the method of Hessel and Modglin ${ }^{12)}$.

On gestation days $14.5,16.5$ and 18.5 , pregnant females (28 control, 32 experimental) were anaesthetized with chloroform and killed by decapitation. The number and location of live, dead and resorbed fetuses were recorded. Live fetuses were observed under a dissecting microscope to examine then for gross physical abnormalities. Heads were fixed in Bouin's solution for 24 hours and then stored in $70 \%$ alcohol. When pregnant fe-
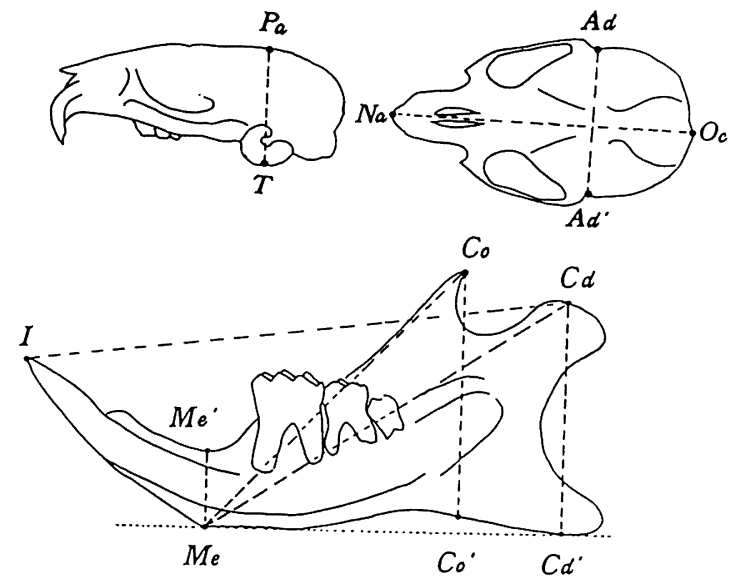

Fig. 1 Landmarks and measurements of skull and mandible.

Skull : $\mathrm{Pa}-\mathrm{T}$ (height), Na-Oc (total length), Ad-Ad' (articulation width). Mandible: Me-Me' (height to the bottom of angular process), Cd.Cd' (condylar height), Co-Co' (coronoid process height), I-Cd (mandible length), Me$\mathrm{Cd}$ (condylar length), Me-Co (coronoid process length).

males (12 control, 40 experimental) gave birth, weights were recorded. Each offspring was weighed daily thereafter. On postnatal days $1.5,3.5,7.5,14.5,21.5$ and 28.5 , skulls and mandibles were removed, weighed and fixed in $4 \%$ paraformaldehyde and $1 \%$ glutar aldehyde. Skulls and mandibles were plac ed directly on X-ray film for obtaining the dorsal and ventral radiographs. Linear measurements of the skull and the mandible were made on the radiographs at 1/1 magnification. (Fig. 1)

Mandibles from postnatal day 3.5 to 28.5 mice were demineralized in $4 \%$ EDT A solu. tion and embedded in paraffin. Sagittal and frontal sections, $4 \mu \mathrm{m}$ thick, were obtained and stained with haematoxylin and eosin $(\mathrm{H}$. E.) and by the Von Kossa's method.

The statistical significance of the difference of the means between the control and experimental groups was examined by Welch-t-test.

\section{Results}

The experimental mice consumed daily 480 $\mathrm{mg}$ of alcohol $(3.1 \mathrm{~m} / / 20 \%$ alcohol $) /$ animal on average. Maternal blood alcohol level 
Table 1 Frequency of resorption in pregnant females

\begin{tabular}{lcc}
\hline & Control & Experimental \\
\hline Pregnant females (P) & 28 & 32 \\
Total implants (T) & 304 & 224 \\
Fetuses (F) & 197 & 89 \\
Litter size (L) & 7.0 & 2.8 \\
\%Resorption (R) & 35.2 & 60.3 \\
\hline
\end{tabular}

$\mathrm{L}=\mathrm{F} / \mathrm{P}, \mathrm{R}=100 \times(\mathrm{T}-\mathrm{F}) / \mathrm{T}$

showed $284.0 \pm 1.4 \mathrm{mg} / 100 \mathrm{~m} l$ on gestation day 12.5. A prolonged gestational period of 22 days was presented in 8 (25\%) of 32 alcoholtreated mothers (vs. 21 days in the control animals). There was an effect of alcohol intake on the litter size (number of fetuses/ one pregnant female). The frequency of fetal resorption was higher in the experimental group than in the control group (Table 1).

Body Weight :

Weights of mother, fetus and offspring (Fig. 2)-No significant differences were found in the maternal body weight between the control and the experimental groups during the four weeks of the prefertilization period (Fig. 2A). Maternal body weights showed significant differences between the two groups during the gestation period (Fig. 2A). Significant differences were found in the fetal body weight between the control and experimental groups on gestation days 14.5, 16.5 and 18.5 (Fig. 2B). Significant differences were found in the body weight of the offsprings during

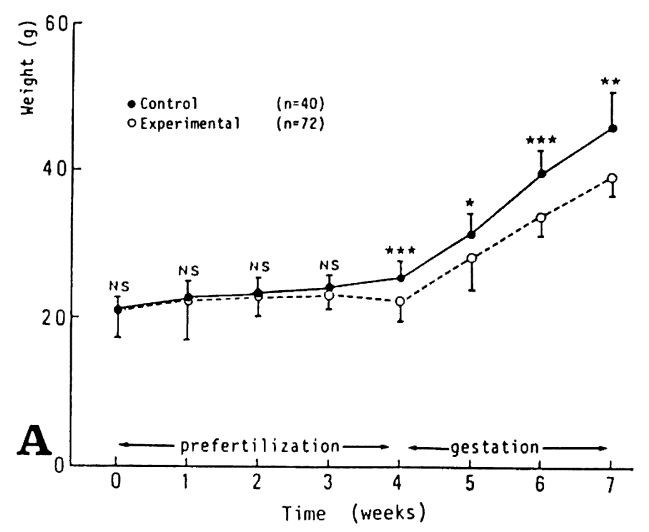

A : Maternal body weight before and during pregnancy.

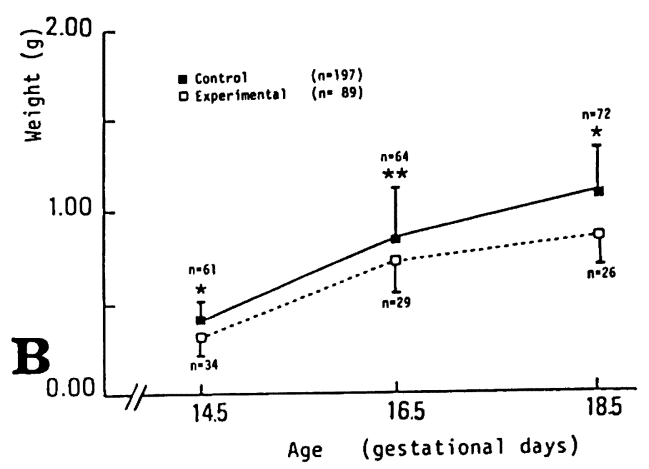

B : Fetal body weight during a gestational period.

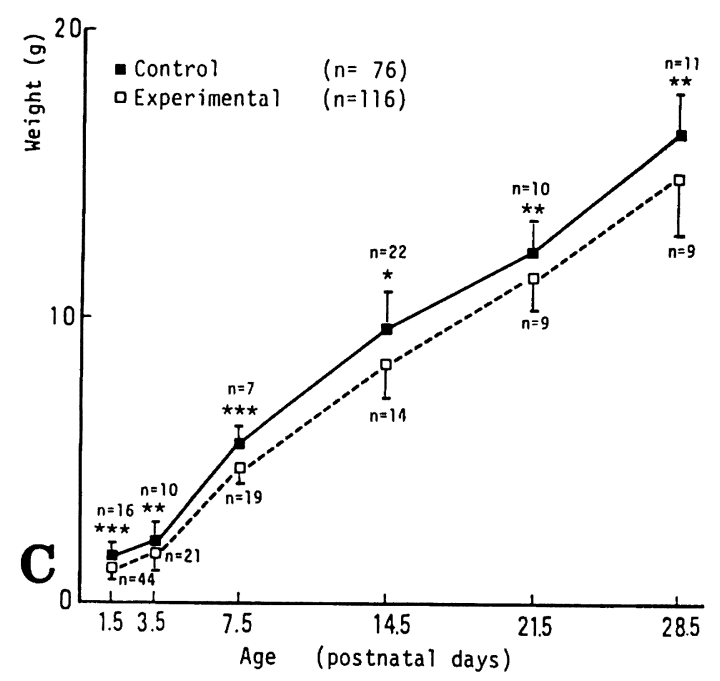

C : Offsprings body weight.

NS (not significant), ${ }^{*} \mathrm{p}<0.05,{ }^{* *} \mathrm{p}<0.01$, ${ }^{* * *} \mathrm{p}<0.001$ (Welch-t-test).

Results are expressed as the mean \pm S.D.

Fig. 2 Body weight.

the four weeks of the postnatal period (Fig. $2 \mathrm{C}$ ). On postnatal day 28.5 , the reduction percentage was 14.4.

Mandible weight (Fig. 3)-Significant differences were found on postnatal days 14.5, 21.5 and 28.5. An increase in the difference was shown from postnatal day 14.5 to 21.5. A decrease in the difference was shown from postnatal day 21.5 to 28.5 . On postnatal day 21.5 , the reduction percentage was 30.8 .

Growth of Skull, Mandible and Tooth:

The differences in the growth of skulls and mandibles between the two groups were mac- 


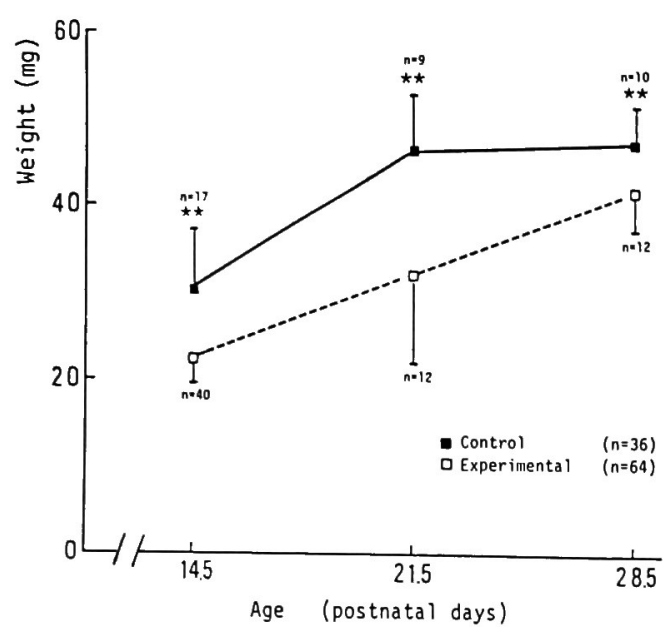

Fig. 3 Mandible weight in postnatal offsprings. ${ }^{* *} \mathrm{p}<0.01$.
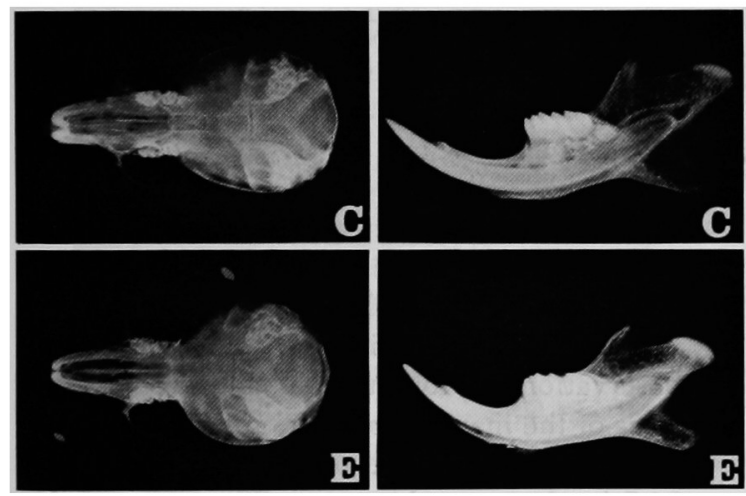

Fig. 4 Radiographs of skulls and mandibles on postnatal day 14.5. Control group (C). Experimental group (E).

roscopically and radiographically appreciable from postnatal day 14.5 (Fig. 4).

Linear measurements of skulls (Fig. 5)-The mean values of the measurements for each postnatal day showed that the height, length and width of the skull increased gradually from postnatal day 14.5 to 28.5. Reduction of the growth was seen in the experimental groups. Significant differences were found in the total length $(\mathrm{Na}-\mathrm{Oc})$ on postnatal days 14.5, 21.5 and 28.5. Significant differences were found in the height $(\mathrm{Pa}-\mathrm{T})$ on postnatal days 14.5 and 21.5 , but not on postnatal day 28.5. No significant differences were found in the articulation width (Ad-Ad') on postnatal days 14.5, 21.5 and 28.5.

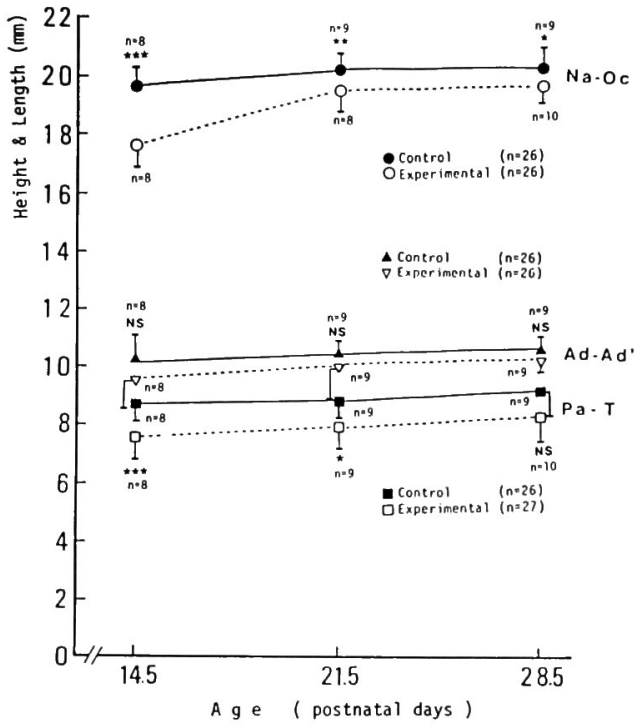

Fig. 5 Linear measurements of skulls in postnatal offsprings.

Length (Na-Oc), Width (Ad-Ad'), $\mathrm{He}$ ight $(\mathrm{Pa}-\mathrm{T})$.

NS (not significant), $\quad{ }^{*} \mathrm{p}<0.05, \quad * * \mathrm{p}<$ $0.01,{ }^{* * *} \mathrm{p}<0.001$.

Linear measurements of mandibles (Fig. 6). The mean values of the measurements for each postnatal day showed that the height and length of the mandible increased gradually from postnatal day 14.5 to 28.5 . Reduction of the growth was seen in the experimental groups. Significant differences were found in the condylar height (Cd-Cd') on postnatal days 14.5, 21.5 and 28.5. On postnatal day 14.5 , significant differences were found in all lengths and heights of the mandibles except the height to the bottom of angular process (Me-Me'). On postnatal day 21.5, no significant differences were found in all lengths and heights of the mandibles except Cd-Cd'. On postnatal day 28.5, significant differences were found in all lengths and heights of the mandibles except the mandible length (I-Cd). Decreases in the differences between the control and experimental groups during a period from postnatal day 14.5 to 21.5 , and increases in the differences from postnatal day 21.5 to 28.5 were shown in the condylar length (Me$\mathrm{Cd}$ ), the coronoid process length (M-Co), the coronoid process height (Co-Co') and $\mathrm{Me}$ Me'. Decreases in the differences from post- 


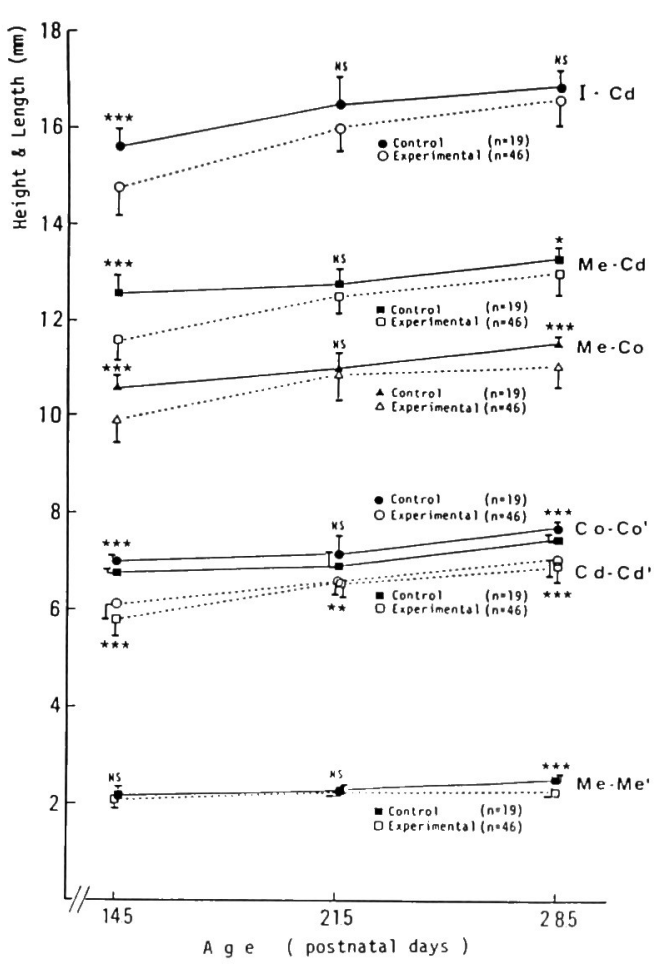

Fig. 6 Linear measurements of mandibles in postnatal offsprings.

Length (I-Cd, Me-Cd, Me-Co), Height (Co-Co', Cd-Cd', Me-Me').

NS (not significant), ${ }^{*} \mathrm{p}<0.05, \quad{ }^{* *} \mathrm{p}<$ $0.01, * * * \mathrm{p}<0.001$.

natal days 14.5 and 28.5 were shown in $\mathrm{Cd}$ Cd' and I.Cd.

Tooth germ (Fig. 7)-Appearance of the tooth germ was histologically shown on gesta- tion day 14.5 in the control group. The oral epithelium proliferated to form the bud at an early developmental stage of the tooth germ of the mandibular first molar. A layer of tall columnar cells appeared adjacent to the future dental papilla (Fig. 7a). The bud of the mandibular first molar showed an early developmental stage on gestation day 14.5 in the experimental group. Thick cuboidal epithelial cells proliferating downward from the dental lamina were present with mitotic fig. ures (Fig. 7b).

Calcification of the tooth (Fig. 8)-Odontoblasts in the most advanced region of the cusps of the mandibular first molar histologically showed the beginning of dentin formation on postnatal day 1.5 in the control group. A continuous layer of calcification was formed adjacent to the dentinoenamel junction as revealed by the Von Kossa's method (Fig. 8a). Dentin matrix in the mandibular first molar on postnatal day 1.5 in the experimental group did not show any sign of calcification (Fig. 8b). Calcification of dentin matrix showed no differences at a light microscopic level between the control and experimental groups from postnatal day 3.5 to 28.5 .

Tooth eruption (Fig. 9)-Light microscopic observations on longitudinal and frontal sections of the mandibular first molar showed the prefunctional eruptive phase on postnatal day 14.5 in the control group. The cusps of the crown approached to the oral mucosa, and the lingual cusp was evidently exposed to the oral cavity. The connective tissue between

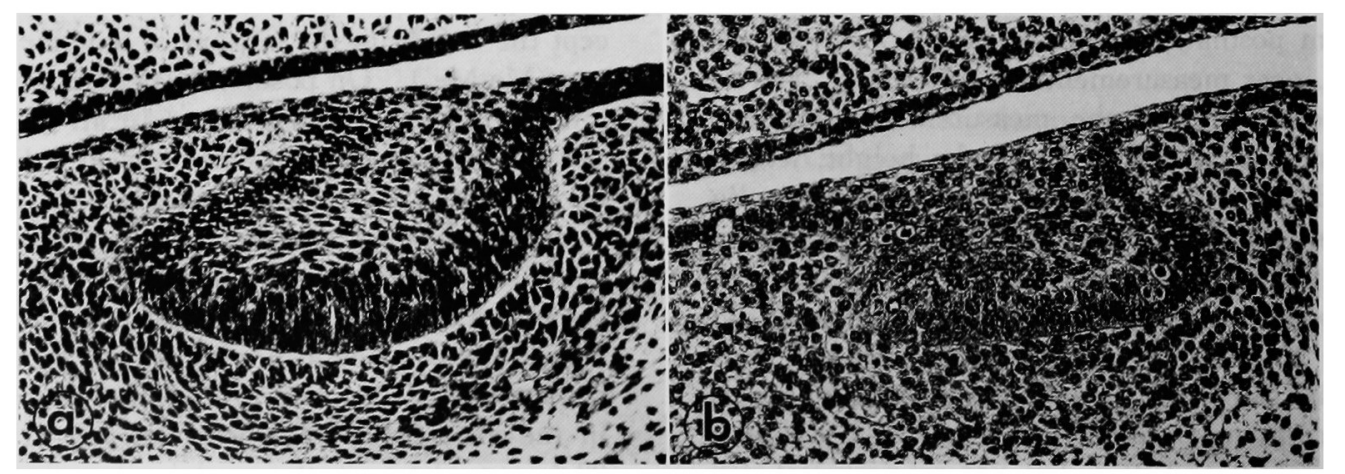

a) Control: An early developmental stage with high columnar cells. b) Experimental : An early developmental stage with thickened cuboidal cells.

Fig. 7 Photomicrographs of the tooth bud of the mandibular first molar on gestation day 14.5. $($ H.E. $\times 200)$ 


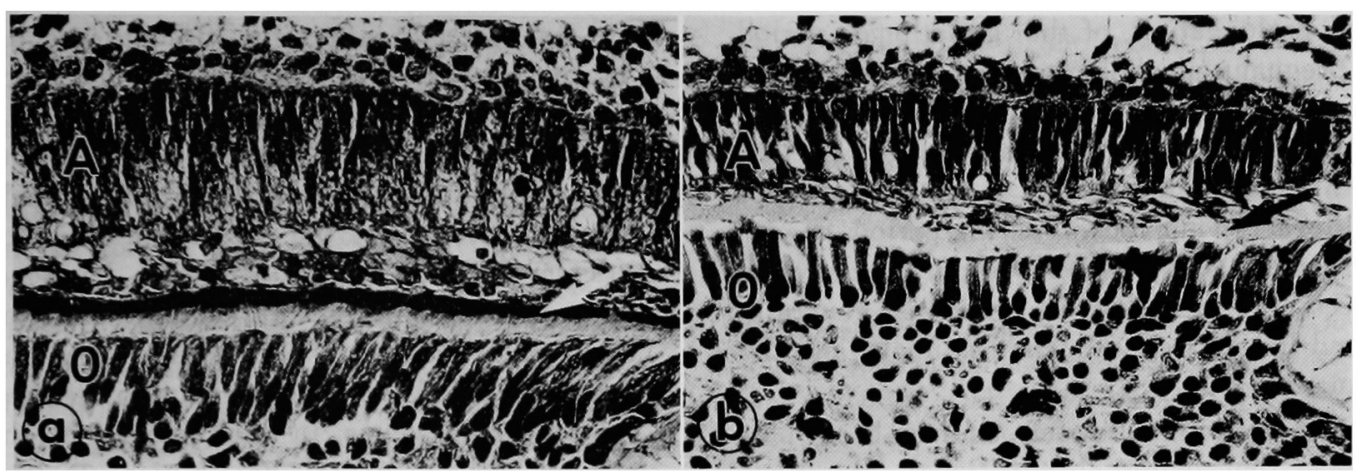

a) Control: Calcification of dentin (an arrow).

b) Experimental : Lack of calcification (an arrow).

Fig. 8 Photomicrographs of longitudinal sections in the most advanced area of the mid-cusp of the mandibular first molar on postnatal day 1.5. Ameloblasts (A). Odontoblasts (O). (Von Kossa's method $\times 200$ )

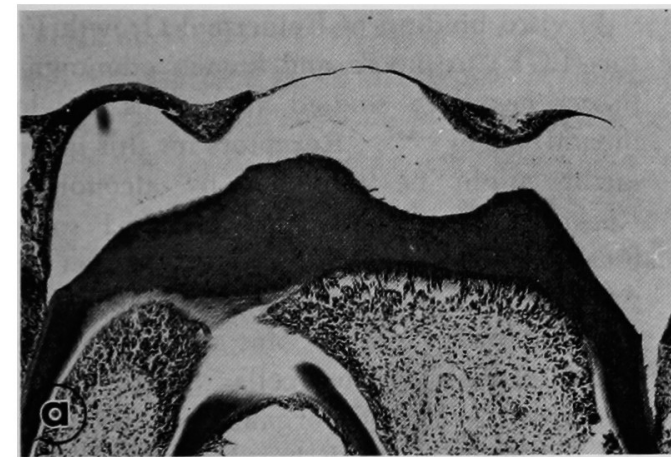

a) Control: Eruptive phase with the lingual cusp emerged into the oral cavity.

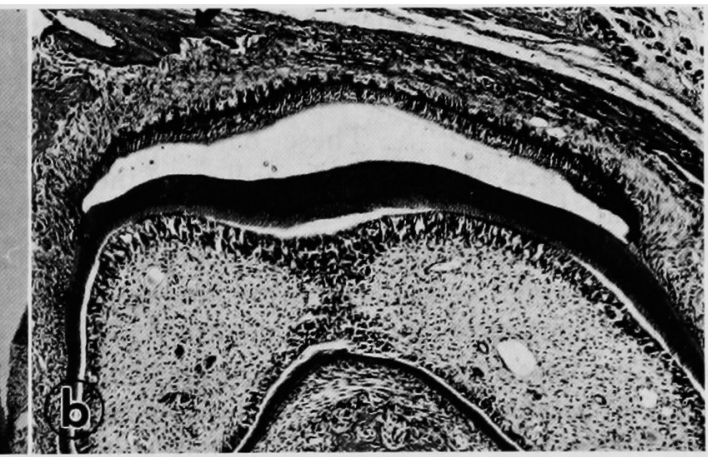

b) Experimental : Maturation phase with normal shape. Alveolar bone (an arrow) overlying the anterior part of the eruptive pathway is seen.

Fig. 9 Photomicrographs of longitudinal sections of the mandibular first molar on postnatal day 14.5. (H.E. $\times 150)$

the dental epithelium and the oral epithelium disappeared. Occlusal surfaces were occasionally covered with the degenerative reduced dental epithelium (Fig. 9a). In the experimental group, the mandibular first molar was surrounded by the fibrous connective tissue. The overlying bone was seen at the surface of the dental epithelia toward which the tooth erupts. There was a close connection between the inner and outer dental epithelia covering the entire enamel surface. These histological features were observed in 10 (66 $\%$ ) of 15 experimental offsprings (Fig. 9b).

\section{Discussion}

Blood alcohol levels are important data for the extrapolation from animal to human. In most cases, animals must be given much higher doses of alcohol to obtain an effect that might occur in human ${ }^{13}$. Animals could metabolize many drugs much faster than hu$\operatorname{man}^{13}$. The mouse and rat, for example, could metabolize alcohol at rates of 300 and 550 $\mathrm{mg} / \mathrm{kg} / \mathrm{hr}$ respectively, whereas in human 100 $\mathrm{mg} / \mathrm{kg} / \mathrm{hr}^{13)}$. Maternal blood alcohol levels of 74 to $98 \mathrm{mg} / 100 \mathrm{~m} l$ had no effect on fetuses in rats ${ }^{14,15)}$. Moderate amounts of alcohol intake during pregnancy did not seem to affect fetuses in the human ${ }^{16,17}$, but preceding and maternal high levels of alcohol intake, particularly at an early stage of pregnancy caused a prenatal effect such as fetal death ${ }^{18-20}$. 
The prolongation of the gestational period in pregnant alcoholic animals has also been reported ${ }^{19}$. A high embryonic resorption rate obtained in this study suggests that even a moderate alcohol intake (blood alcohol level $284 \mathrm{mg} / 100 \mathrm{~m} l$ ) during periods of prefertilization and pregnancy might have adverse effects on gestation in mice as generally found in other experimental animals, and the

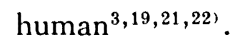

In most animal models, it has been postulated that maternal nutritional alterations would be a primary interactive factor in $\mathrm{FAS}^{6,23,24)}$. Furthermore there has been a report that the degree of FAS was dependent upon the state of the maternal liver and not on amounts of alcohol intake ${ }^{25}$. On the other hand, alcoholic mothers showed decreases in their body weight and in the number of offsprings, compared with isocaloric fed control mothers ${ }^{19,26,27)}$. These data reflect the direct effects of alcohol, regardless of the nutritional factors ${ }^{18,26,27)}$. The detrimental effect on the fetal weight was potentiated in the offspring of alcohol-treated mothers. Alcoholic mothers weighed less than the controls at the time of pregnancy. Lower body weight of mothers at the impregnation time might result in a risk to the offsprings with lower body and mandible weights at birth.

Considerable evidences have shown that alcohol inhibited the brain development and was exerted on the skull growth and expan$\operatorname{sion}^{28,29)}$. The reduction of skull length may be a manifestation of disorganized neural and mesenchymal growth ${ }^{28}$. Linear measure. ments of skulls in this study may suggest the retardation of active growth at cranial sutural sites. Growth of the human brain begins shortly after organogenesis reaches a maximum rate around birth and continues through the first few years of life ${ }^{30,31}$. Maxillary and mandibular hypoplasia have been reported in severe human and animal FAS cases. $^{1,14,25,28)}$. Linear measurements of mandibles in this study show that the initial target of alcohol was the posterior region of the mandible. This may be explained by the teratogenic action of alcohol on the mitotic activity of the condyle playing an important role in the mandibular growth. Blood alco- hol can directly affect the placenta and has adverse effects on the calcium balance ${ }^{32)}$ and ossification. Alcohol passing through the placenta has teratogenic effects on organ growth and enzymatic effects on electrolyte metabolism $^{\text {s3). }}$. However, the subsequent effects on calcium balance in the offspring have not been reported, except for some reports on transient hypocalcemia in children with human FAS $^{11}$. Alcohol may relate to the fetal development ${ }^{33)}$ even in the absence of the obvious developmental or physical malformations. The subtle effects may last into adulthood with hypoplasic characteristics of FAS $^{11}$. Observations of dental tissues had showed alterations of tooth size and faulty enamel formation in human $\mathrm{FAS}^{34}$.

In vitro binding of Epidermal Growth Factor (EGF) to mouse and human odontogenic tissues has been studied at various developmental stages ${ }^{35-37)}$. Receptors for this growth factor might be inhibited by alcohol ${ }^{38,39}$. Recent studies on the binding of EGF to various odontogenic tissues suggest that this growth factor may have a significant role in the development of tooth organs and the differentiation of mesenchymal cells. Retardation of the growth of tooth organs may be due to the inhibition of EGF by alcohol.

The basic architecture of the tooth is established during embryogenesis. It is regulated by sequential epithelio-mesenchymal interactions, especially at an early developmental stage of the tooth before calcification of dentin begins. Delayed calcification of dentin might not be caused by derangements and disruptions of developing tissues, but rather be a result of reduction of cells followed by delayed functions ${ }^{40)}$. A recent ultrastructural study on tooth germs from mini-pig ftuses in alcoholtreated mothers has reported that mitochon. dria of secretary ameloblasts showed abnormal shapes and deposition of paracrystalline material in the matrix ${ }^{41}$.

The mechanisms of tooth eruption seem to be multifactorial processes ${ }^{42}$. The rate of tooth eruption is abnormal in several pathological conditions and syndromes (i.e., cleidocranial dysplasia, Down syndrome ${ }^{43)}$ and osteopetrotic animals $\left.{ }^{44}\right)$. Retardation of tooth eruption has been shown in offsprings of ma- 
caque monkeys whose mothers were exposed to alcohol ${ }^{45)}$. In the apical tissues of developing tooth root, EGF uptake with heavy labeling of vessel walls and dental mesenchymal cells has recently been shown by Thesleff ${ }^{42}$. One of the in vivo effects of EGF was the precocious incisor eruption in newborn mice $^{46}$. Mechanisms of tooth eruption and those responsible for the tooth precocity by EGF injection are not fully understood yet.

This study showed that alcohol affected the general growth of the fetus and offspring of mice, although a postnatal experimental period was not long enough to demonstrate the alterations in the adulthood. The mecha- nisms of action of alcohol could be due to a variety of processes, including the interactions at membrane levels of developing cells, and to the alterations in growth factors and cellular metabolism needed for normal growth.

\section{Acknowledgement}

The author is grateful of Professor K. Ooya for his continuous guidance and helpful advice, and to Dr. T. Ohkubo for his kind suggestions and excellent technical assistance. A part of this article was presented at the 37th Annual Meeting of Japanese Association for Dental Research in December 1989.

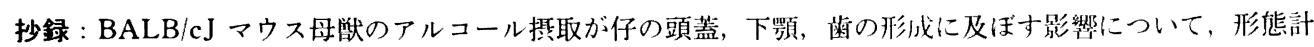
测・病理組織学的に観察した。実験群には妊娠前，妊娠中に $20 \%$ のアルコールを，正常群には水を自由攝取 させた。母獣の血中アルコール䟴度は妊張 12.5 日で $284.0 \pm 1.4 \mathrm{mg} / 100 \mathrm{ml}$ を示した。その結果，1）母獣の体 重に有意差はなかったが，仔の体重の軽量化がみられた。2）出生後28.5日に至る仔の下䪽骨重量の柽量化が みられた。3）出生後14.5，21.5，28.5日の下預骨には発育遅延がみられ，下䫈骨後方の成長に明らかな有意 差がみられた。4）歯胚の形成は出生後14.5日で差異がみられた。5）歯の石灰化は出生後1.5日で差異がみら れた。6）歯の萌出遅延は出生後14.5日でみられた。以上より，母獣のアルコール中毒は，仔の頭蓋，下顎， 歯の形成過程に影響し，出生後 4 週ではその回復はみられないことが判明した。

\section{References}

1) Jones, K. L., Smith, D. W., Ulleland, C. N. and Streissguth, A. P. : Pattern of malformation in offspring of chronic alcoholic mothers. Lancet 3: 1267-1271, 1973.

2) Clarren, S. K. and Smith, D. W. : The fetal alcohol syndrome. New Engl. J. Med. 298 : 1063-1067, 1973.

3) Abel, E. L. : Consumption of alcohol during pregnancy: A review of effects on growth and development of offspring. Hum. Biol. 54 : 421-453, 1982.

4) Streissguth, A. P., Landesman-Dwyer, S., Martin, J. C. and Smith, D. W.: Teratogenic effects of alcohol in humans and laboratory animals. Science $209: 353-361,1980$.

5) Sandor, S. and Doina Amels: The action of aethanol on the praenatal development of albino rats (An attempt of multiphasic screening). Rev. Roum. Embryol. Cytol. Ser. Embryol. 8 : 105-118, 1971.

6) Chernoff, G. F.: A mouse model of the fetal alcohol syndrome. Teratology 11:14 A, 1975.

7) Bauer-Moffett, C. and Altman, J.: The ef- fect of ethanol chronically administered to preweanling rats on cerebellar development : A morphological study. Brain Res. 119 : 249 268, 1977.

8) Epstein, D. L. and Sucheston, M. E. : Morphometric analysis of the craniofacial devel. opment of the CD-1 mouse fetus exposed to alcohol on gestational day eight. J. Craniofacial Genet. Dev. Biol. 7 : 267-283, 1987.

9) Elmer, G. I., Meisch, R. A. and George, F. R. : Differential concentration-response curves for oral ethanol self-administration in C57BL/6J and BALB/cJ mice. Alcohol 4 : 63-68, 1987.

10) Kronick, J. B. : Teratogenic effects of ethyl alcohol administered to pregnant mice. Am. J. Obstet. Gynecol. 124 : 676-680, 1976.

11) Cassells, B., Wainwright, P. and Blom, K. : Heredity and alcohol-induced brain anomalies: Effects of alcohol on anomalous prenatal development of the corpus callosum and anterior commissure in $\mathrm{BALB} / \mathrm{c}$ and $\mathrm{C} 57 \mathrm{BL} /$ 6 mice. Exp. Neurol. 95:587-604, 1987.

12) Hessel, D. W. and Modglin, F. R.: The quantitative determination of ethanol and other volatile substances in blood by gas-liquid 
partition chromatography. J. Forensic j̀ci. 9 : 255-264, 1964.

13) Abel, E. L. : Procedural considerations 1. evaluating prenatal effects of alcohol in animals. Neurobehav. Toxicol. 2 : 167-174, 1980.

14) Giglio, M. J., Vieiro, M., Friedman, $S$ and Bozzini, C. E.: Effect of renital etl inol exposure on the growth of rat randitble skeletal units. J. Biol. Buccale $15: 211-216$, 1987.

15) Samson, H. H. : Maternal ethanol consumption and fetal development in the rat: A comparison of ethanol exposure techniquas. Alcoholism: Clin. Exp. Res. 5 : 67-74, 1981.

16) Ouellette, E. M., Rosett, H. L., Rosman, N. P. and Weiner, L.: Adverse effects on offspring of maternal alcohol abuse during pregnancy. New Engl. J. Med. 297 : 528530, 1977.

17) Halmesmäki, E., Raivio, K. O. and Ylikorkala, O.: Patterns of alcohol consumption during pregnancy. Obstet. Gynecol. 69 : 594-597, 1987.

18) Little, R. E., Graham, Jr., J. M. and Samson, H. H. : Fetal alcohol effects in humans and animals. Adv. Alc. Subs. Abuse 1 : 103-125, 1982.

19) Gianoulakis, C. : Effect of prenatal exposure to ethanol on body growth and the pituitary $\beta$-endorphin. Alcoholism: Clin. Exp. Res. 11 : 567-573, 1987.

20) Jones, K. L. and Smith, D. W. : Recognition of the fetal alcohol syndrome in early infancy. Lancet 3: 999-1001, 1973.

21) Ellis, F. W. and Pick, J. R. : An animal model of the fetal alcohol syndrome in beagles. Alcoholism: Clin. Exp. Res. 4 : 123134, 1980.

22) Nyquist-Battie, C., Uphoff, C. and Cole, T. B. : Maternal ethanol consumption: Effect on skeletal muscle development in guinea pig offspring. Alcohol 4: 11-16, 1987.

23) Schwetz, B. A., Smith, F. A. and Staples, R. E. : Teratogenic potential of ethanol in mice, rats and rabbits. Teratology $18: 385-$ $392,1978$.

24) Pullen, G. L., Singh, S. P. and Snyder, A. K.: Growth patterns of the offspring of al. cohol-fed rats. Growth Dev. Aging 52 : 8589, 1988.

25) Majewski, F.: Alcohol embryopathy :Some facts and speculations about pathogenesis. Neurobehav. Toxicol. Teratol. $3:$ 129-144, 1981.

26) Tze, W. J. and Lee, M, : Adverse effects of maternal alcohol consumption on pregnancy and foetal growth in rats. Nature 257 : 479-480, 1975.

27) Sorette, M. P., Maggio, C. A., Starpoli, A., Boissevain, A. and Greenwood, M. R. C. : Maternal ethanol intake affects rat organ development despite adequate nutrition. Neurobehav. Toxicol. 2 : 181-188, 1980.

Padmanabhan, R. and Muawad, W. M. R. A : Exencephaly and axial skeletal dysmor. phogenesis induced by acute doses of ethanol in mouse fetuses. Drug Alcohol Depend. 16: $215-227,1985$.

29) Moss M. L. and Young, R. W. : A functiona) approach to craniology. Am. J. Phys. Anthro:) 18 : 281-292, 1960.

30) Dobbing. J. and Sands, J.: Quantitative growth ind development of human brain. Arch. Dis. Child. 48 : 757-767, 1973.

31) Samsol, H. H. and Grant, K. A. : Fetal alcohol effects: Alcohol and the developing nervous system of the rat. Progr. Alcohol Res. $1: 1-35,1985$.

32) Baran, D. T. . Byant, C. and Robson, D. : Alcohol-induce: a!terations in calcium metab. olism in the 1 exrnant rat. Am. J. Clin. Nutr. $36: 41-44, \quad 982$.

33) Desroches, D., Ryan, K.. Vleck, E. and Benno, R. H.: Effects of acute, in utero, alcohol exposure on growth and electrolyte metabolism in male offspi:ng of C57BL/10J mice. Alcohol Drug Res. 7 : 415-422, 1987.

34) Wood, R. E. : Fetal alcohol syndrome: its implications for dentistry. J. Am. Dent. Assoc. 95 : 596-599, 1977.

35) Partanen, A.-M. and Thesleff, I. : Localization and quantitation of ${ }^{125}$ I-epidermal growth factor binding in mouse embryonic tooth and other embryonic tissues at different developmental stages. Dev. Biol. 120 : 186-197, 1987.

36) Snead, M. L., Luo, W., Oliver, P., Nakamura, M., Don-Wheeler, G., Bessem, C., Bell, G. I., Rall, L. B. and Slavkin, H. C. : Localization of epidermal growth factor precursor in tooth and lung during embryonic mouse development. Dev. Biol. 134 : 420429, 1989.

37) Steidler, N. E. and Reade, P. C.: Epidermal growth factor and proliferation of odontogenic cells in culture. J. Dent. Res. 60 : 1977-1982, 1981.

38) Thesleff, I., Ekblom, P. and Keski-Oja, J. : Inhibition of morphogenesis and stimulation of vascular proliferation in embryonic tooth cultures by a sarcoma growth factor prepa. 
ration. Cancer Res. 43 : 5902-5909, 1983.

39) Gerhart, M. J., Reed, B. Y. and Veech, R. L. : Ethanol inhibits some of the early effects of epidermal growth factor in vivo. Alcoholism : Clin. Exp. Res. 12 : 116-118, 1988.

40) Webb, S., Hochberg, M. S. and Sher, M. R. : Fetal alcohol syndrome : report of case. J. Am. Dent. Assoc. 116 : 196-198, 1988.

41) Matthiessen, M. E. and R $\phi$ mert, P. : Changes of secretory ameloblasts in mini-pig fetuses exposed to ethanol in vivo. J. Dent. Res. 67 : 1402-1404, 1988

42) Thesleff, I., Partanen, A.-M. and Rihtniemi, L. : Localization of epidermal growth factor receptors in mouse incisors and human premolars during eruption. Eur. J. Orthod. 9 : 24-32, 1987.
43) Gorlin, R. J., Pindborg J. J. and Cohen M. M., Jr. : Syndromes of the head and neck 2 nd edn., pp.96-97, McGraw.Hill, 1976.

44) Marks, S. C., Jr.: Tooth eruption and bone resorption : experimental investigation of the ia (osteopetrotic) rat as a model for studying their relationships. J. Oral Pathol. 5: 149163, 1976.

45) Bowden, D. M., Weathersbee, P. S., Clarren, S. K., Fahrenbruch, C. E., Goodlin, B. L. and Caffery, S. A. : A periodic dosing model of fetal alcohol syndrome in the pigtailed macaque (Macaca nemestrina) Am. J. Primatol. 4 : 143-157, 1983.

46) Cohen, S. : Isolation of a mouse submaxillary gland protein accelerating incisor eruption and eyelid opening in the new-born animal. J. Biol. Chem. 237 : 1555-1562, 1962. 